\title{
Political fallout anticipated
}

\section{Tokyo}

As details of the emergency shutdown of the number two reactor of the Mihama nuclear power plant begin to leak out, it is becoming clear that Mihama is the most serious accident ever in the history of Japanese nuclear power. Although there were only small releases of radioactivity into the local environment, the political fallout from the accident is likely to be much more serious.

Inspection of the primary cooling system with a fibrescope has revealed that one of the thin tubes in the heat exchanger of the primary system was blown open, and rapid leakage of primary coolant into the secondary cooling system activated the emergency cooling system. A similar accident occurred at the North Anna plant in Virginia in the United States in 1987, but Japanese government and nuclear industry officials, who pride themselves on their strict periodic safety checks of nuclear plants, had claimed that such an accident could never occur in Japan. The pipe at Mihama that broke open had passed such a safety check with flying colours last July.

According to the latest reports, when the pipe blew, 50 to 100 tons of radioactive steam poured into the secondary cooling system which drives the plant's turbine -

\section{PR blunders}

THE day after the Mihama accident, about 30,000 local residents in the area surrounding the plant opened their newspapers to find a public-relations pamphlet from Kansai Electric Power Company proclaiming the wonders and safety of nuclear power, according to a Kyodo wire service report. Apparently the company, which operates the Mihama plant, failed to withdraw the leaflet because its employees were too busy dealing with the accident.

In describing the cooling system of nuclear power plants, the pamphlet claimed that "high performance" robots can "detect even pinholes that human eyes cannot see", thereby allowing preemptive repairs to be carried out. It was a gaping hole in the primary cooling system that caused the Mihama accident.

And things became even more embarrassing for the hapless power company. Mihama plant holds regular tours of its facility for the public. At the time of the accident, ninety-four such visitors were inside the plant, and some reported seeing steam emanating from the turbine room as the reactor was shut down. Fortunately, the visitors were unaware that a major accident was in progress.

D.S. much more than the 20 tons initially estimated (see Nature 349, 557; 1991). And contrary to early official announcements that no radioactivity was released into the local environment, it has now been revealed that radioactive steam was vented from the secondary system into the atmosphere and sea when the primary system blew. But the small amounts of radioactivity went undetected by monitors surrounding the plant, which continued to show background radiation levels.

The timing of the accident was "very bad", say officials of the Ministry of International Trade and Industry (MITI), the government body in charge of the nuclear power industry. Public fears of nuclear power had begun to calm down after the Chernobyl accident, and a pro-nuclear candidate was elected recently as governor in Aomori prefecture where government and industry are establishing a huge facility for enrichment and reprocessing of nuclear fuel and storage of nuclear waste (see Nature 349, 449; 1991).

Several days after the accident, government and industry officials revealed that a safety valve designed to relieve pressure in the primary cooling system in case of leaks failed to function. Plant operators had to use a backup system that sprays water into the primary coolant to relieve pressure. As a result, the release of radioactive steam from the secondary system into the environment was larger than if the valve had worked.

Ryuji Fuji, director for international affairs on nuclear power safety in MITI's Agency of Natural Resources and Energy, says that MITI did not immediately announce the failure of the valve because its prime concern was to reassure the public that the local environment had not been seriously contaminated with radiation. But the delay runs counter to government pronouncements that it wants to win public understanding through open and scientific explanation of the safety of nuclear power.

Haruo Suzuki, director of the office of nuclear safety policy research at the Science and Technology Agency, says that from the political point of view the accident is "very severe". For the past few years, the government and the nuclear power industry have been spending millions of dollars on public relations campaigns designed to reassure the public about the safety of Japanese nuclear power in the wake of Chernobyl. Mihama has blown a gaping hole in all those efforts.

In addition to a mandatory investigation by the Nuclear Safety Commission, Prime Minister Toshiki Kaifu has called for a cabinet-level investigation of the accident, and MITI will establish a com-

\section{The Lords weigh in}

\section{London}

THE influential House of Lords Science and Technology Committee has launched an inquiry into the 1991-92 UK science budget, an action that could ultimately lead to pressure on the government to change its science funding policies. The recently announced science budget precipitated a funding crisis in the research councils, culminating in a savage package of cuts by the Science and Engineering Research Council (SERC; see Nature 349, 551; 14 February 1991).

The committee aims to discover whether the research councils' difficulties are primarily the result of the government's failure to increase funding to match inflation, of increasing subscriptions to international science projects, or poor financial management by the research councils themselves. Speaking in the House of Commons on 6 February, Education and Science Secretary Kenneth Clarke laid the blame for the current round of cuts at the door of SERC under its previous chairman, Sir William Mitchell, who stepped down last autumn. SERC had embarked on a series of large commitments that outran its resources, he said.

Unusually, the new inquiry will be conducted by the full 16-member Science and Technology Committee, rather than a small subcommittee. The inquiry's findings will be published in a short report in the coming months. Although the government is not obliged to act on the committee's recommendations, pressure from the committee has influenced UK science policy in the past. The committee will meet Sir Mark Richmond, SERC chairman, and Sir Peter Swinnerton-Dyer, chief executive of the Universities Funding Council, next week. Peter Aldhous

mittee of 20 experts to look into the affair.

Japan has 17 pressurized water reactors (PWRs) like Mihama currently in operation. Of these, four have had more than 10 per cent of the thousands of thin primary tubes in their heat exchanger plugged because of leaks, according to Fuji. This compares with only 6 per cent plugging in the Mihama No. 2 reactor, which blew.

The government has no plans to close these other plants for inspection. Instead, MITI has simply advised the power companies to make their periodic inspections more stringent.

But the most serious potential fallout from the accident concerns MITI's ambitious plans to build 40 more nuclear power plants in Japan by 2010 . Before the accident, the government was already having difficulty winning public acceptance of proposed sites, and Mihama will make siting even more difficult.

David Swinbanks 